\title{
MENINGKATKAN HASIL BELAJAR SISWA MELALUI PENGGUNAAN ALAT PERAGA PADA MATERI GEOMETRI RUANG
}

\author{
Rya Uli Situmorang ${ }^{1}$, Nurapni Sopia ${ }^{2}$ \\ ${ }^{1}$ STKIP Persada Khatulistiwa Sintang, ${ }^{2}$ SMA Negeri 2 Sekadau \\ email: ${ }^{1}$ ryaulisitumorang3@gmail.com, ${ }^{2}$ nurapni22sopia@gmail.com
}

\begin{abstract}
The purpose of this study was to determine the factors that cause the low student learning outcomes in space geometry material, describe the use of teaching aids in improving learning outcomes in space geometry material. As well as knowing the increase in learning outcomes in students geometry space by using teaching aids. This is attempted to overcome the problem of low student learning outcomes and have not yet reached the Minimum Mastery Learning Standards $(S K B M)$. The method used in this paper is a quantitative method by looking at student learning outcomes obtained from direct experience in the use of teaching aids on building materials in class XA SMAN 2 Sekadau and supported by literature studies. There are two factors that cause the low student learning outcomes, namely: (1) internal factors include physiological and psychological, and (2) external factors include family, school, and community. Based on the results of research on the use of cube frame props can improve student learning outcomes in class X SMAN 2 Sekadau on geometry material space (determine the distance between points, points to lines, and points to the field) by $29.2 \%$ and achieve completeness classically by $88,4 \%$
\end{abstract}

Keywords: Learning Outcomes, Teaching Aids, Geometry

\begin{abstract}
Abstrak. Tujuan dalam penelitian ini untuk mengetahui faktor-faktor penyebab rendahnya hasil belajar siswa pada materi geometri ruang, mendeskripsikan penggunaan alat peraga dalam meningkatkan hasil belajar pada materi geometri ruang. Serta mengetahui peningkatan hasil belajar geometri ruang pada siswa dengan menggunakan alat peraga. Hal ini diupayak guna mengatasi masalah hasil belajar siswa yang rendah dan belum mencapai Standar Ketuntasan Belajar Minimal (SKBM). Metode yang dilakukan dalam tulisan ini yaitu metode kuantitatif dengan melihat hasil belajar siswa diperoleh dari pengalaman langsung dalam penggunaan alat peraga pada materi bangun ruang di kelas XA SMAN 2 Sekadau serta didukung studi literatur. Ada dua factor yang menjadi penyebab rendahnya hasil belajar siswa yakni: (1) faktor internal meliputi fisiologis dan psikologis, dan (2) faktor eksternal meliputi keluarga, sekolah, dan masyarakat. Berdasarkan hasil penelitian penggunaan alat peraga rangka kubus dapat meningkatkan hasil belajar siswa kelas X SMAN 2 Sekadau pada materi geometri ruang (menentukan jarak antar titik, titik ke garis, dan titik ke bidang) sebesar 29,2\% dan mencapai ketuntasan secara klasikal sebesar 88,4\%.
\end{abstract}

Kata Kunci: Hasil Belajar, Alat Peraga, Geometri Ruang 


\section{PENDAHULUAN}

Berbagai upaya telah dilakukan guru guna meningkatkan mutu pembelajaran. Salah satu upaya tersebut yakni melalui Musyawarah Guru Mata Pelajaran (MGMP) yang mengedepankan pembaharuan kurikulum, perbaikan sistem pengajaran serta peningkatan kemampuan guru. Seluruh kegiatan yang dilakukan oleh MGMP khususnya matematika merupakan usaha dengan satu tujuan bersama yakni demi terciptanya proses belajar mengajar yang menyenangkan dan bermakna.

Pada umumnya pelajaran matematika dianggap oleh mayoritas siswa sebagai pelajaran yang dianggap sulit dipahami. Jika kondisi ini diteruskan dari tahun ke tahun maka anggapan-anggapan negatif mengenai matematika akan tetap melekat bahkan cenderung menetap dalam pemikiran siswa secara turun temurun.

Pernyataan negative tersebut diperkuat dengan adanya pengalaman penulis menjadi guru matematika yang memberikan pembelajaran dengan pokok bahasan geometri bangun ruang kepada siswa SMA $\mathrm{N} 2$ Sekadau. Ketika pembelajaran selesai dilaksanakan penulis mengevaluasi kembali ternyata ada sebagian besar siswa mengalami kesulitan dalam mempelajari materi bangun ruang yang bersifat abstrak. Ada beberapa faktor yang menyebabkan kesulitan tersebut salah satu diantaranya yakni minat siswa sangat kurang dalam mempelajari geometri bangun ruang. Hal ini diketahui jika siswa diberikan permasalahan mengenai geometri bangun ruang khususnya kubus, sebagian siswa tidak dapat menemukan penyelesaian dengan berbagai alasan yang berbeda. Alasan siswa antara lain ditunjukkan dengan ketidakmengertian pada cara menjawab dikarenakan soal tidak sama dengan contoh yang diberikan. Selain itu juga masih banyak siswa malas-malasan, ada yang baring-baring di atas meja, dan asik berbicara dengan teman sebangkunya. Sehingga berdampak pada waktu pengumpulan tugas dengan waktu yang hanya tinggal beberapa menit lagi, siswa tersebut akan mencontek atau menyalin jawaban yang dianggap benar dari teman yang memiliki kemmapuan lebih.

Oleh karena itu, untuk mengatasi halhal yang telah diuraikan di atas, penulis berupaya membimbing siswa dalam mempelajari geometri bangun ruang melalui sketsa/gambar dari bangun ruang. Setelah pembelajaran tersebut dilakukan hasil belajar siswa belum juga sesuai dengan yang diharapkan, yang dibuktikan dengan masih banyak siswa yang memiliki nilai kurang dari Standar Ketuntasan Belajar Minimal (SKBM).

Menurut penulis salah satu yang mendasar sehingga menjadi penyebab kesulitan belajar yang dihadapi siswa ini adalah kekurangmampuan siswa dalam berpikir abstrak dan pemahaman konsepkonsep matematika yang bersifat abstrak. Akhirnya berdampak pada rendahnya hasil belajar siswa dalam mempelajari bangun ruang, sehingga menjadi suatu permasalahan yang harus diselesaikan karena akan berdampak pula terhadap proses pembelajaran selanjutnya. Oleh sebab itu, untuk mengatasi 
masalah tersebut penulis melakukan penelitian dengan judul "Meningkatkan hasil belajar siswa melalui penggunaan Alat Peraga pada materi geometri ruang di kelas XA SMAN 2 Sekadau" dengan tujuan untuk mengetahui faktor-faktor penyebab rendahnya hasil belajar siswa pada materi geometri bangun ruang, mendeskripsikan penggunaan alat peraga dalam meningkatkan hasil belajar pada materi geometri bangun ruang. Serta mengetahui peningkatan hasil belajar geometri bangun ruang pada siswa dengan menggunakan alat peraga.

\section{METODE}

Metode yang digunakan dalam penelitian ini yaitu metode kuantitatif. Menurut Priyono (2016:14) metode penelitian kuantitatif adalah perolehan data yang berbentuk angka atau data kualitatif yang disajikan dalam angka. Metode ini direalisasikan dengan memberikan soal atau tes tertulis yang beberntuk uraian mengenai geometri bangun ruang yang terlebih dahulu divalidasi oleh 2 orang teman sejawat, dan realibilitas serta tingkat kesukaran yang kemudian direvisi kembali. Selanjutnya, diujicobakan dan direvisi lagi sebelum digunakan dalam penelitian. Sehingga diperoleh hasil belajar siswa yang berbentuk skor, setelah diberikan perlakukan yakni pembelajaran dengan menggunakan alat peraga terhadap materi geometri bangun ruang di kelas XA SMAN 2 Sekadau. Hal ini didasarkan dengan pernyataan yang di utarakan oleh Nawawi (2004:24) yakni "hasil belajar siswa merupakan tingkat keberhasilan siswa dalam bentuk skor yang diperoleh dari tes mengenai sejumlah materi tertentu". Hasil belajar yang diperoleh dalam bentuk skor kemudian diolah melalui program microsft exccel sehingga rata-rata hasil belajar dapat diketahui. Selanjutnya jawaban siswa dianalisis berdasarkan pertanyaan per item untuk mengetahui kesulitan dalam memahami geometri bangun ruang.

Setelah analisis dilakukan, penulis memberikan angket tertutup yang terlebih dahulu di validasi oleh 2 orang teman sejawat guna mengetahui faktor apa saja yang menjadi kendala dalam kurangnya pemahaman akan geometri bangun ruang. Menurut Sugiyono (2017:199) angket merupakan teknik pengumpulan data yang dilakukan dengan cara memberi seperangkat pernyataan tertulis kepada responden untuk dijawab. Angket dalam penelitian ini terdiri dari 10 item pernyataan negatif dan 10 item pernyataan positif yang keseluruhannya menjadi 20 pernyataan. Isi angket berkaitan dengan faktor-faktor yang menjadi penyebab rendahnya hasi belajar siswa pada materi geometri bangun ruang. Hasil angket dianalisis menggunakan skala likert.

\section{HASIL DAN PEMBAHASAN}

Faktor-faktor Penyebab Rendahnya Hasil Belajar Siswa Pada materi Geometri Bangun Ruang

Tingkat pemahaman dan penguasaan materi sangat mempengaruhi hasil belajar karena semakin tinggi pemahaman dan penguasaan maka semakin tinggi pula tingkat keberhasilan pembelajaran. Hal ini berbanding 
terbalik pada kenyataan yang dapat dilihat bahwa hasil belajar matematika yang dicapai siswa masih rendah.

Beberapa faktor yang mempengaruhi hasil belajar, sebagai berikut: 1) Faktor internal adalah faktor yang ada dalam diri individu yang sedang belajar meliputi faktor fisiologis seperti kesehatan yang prima, tidak dalam keadaan lelah, dan cacat jasmani, faktor psikologis seperti intelegensi (IQ), perhatian, minat, motivasi, kognitif dan daya nalar siswa; 2) Faktor eksternal adalah faktor yang ada di luar individu meliputi faktor keluarga, faktor sekolah, dan faktor masyarakat.

Berdasarkan hasil analisis angket diperoleh rendahnya hasil belajar siswa kelas $X$ di SMAN 2 Sekadau akibat dari pengetahuan yang hanya diterima begitu saja sehingga informasi dari guru kurang bermakna dalam kehidupan sehari-hari atau dengan kata lain ketika pembelajaran berlangsung hanya mendengar saja tanpa adanya pemahaman yang mendalam.. Penyebab rendahnya hasil belajar siswa kelas X SMAN 2 Sekadau terletak pada lemahnya (a). Keterampilan siswa dalam menggambar dan menggunakan alat-alat untuk menggambar bangun-bangun ruang tiga dimensi masih rendah, (b).

Kemampuan pemahaman konsep matematika siswa masih kurang memuaskan, (c). Sebagian siswa hanya mengandalkan hafalan tanpa memahami konsep sehingga melakukan kesalahan dalam menyelesaikan soal, (d). Materi prasyarat diantaranya adalah garis lurus, sudut, luas bangun datar, trigonometri dan syarat-syarat berlakunya teorema
Phytagoras belum dikuasai oleh sebagian siswa. Hal ini diketahui pada saat pengerjaan postest siswa tidak memahami konsep geometri bangun ruang yang dirasakan sangat abstrak sehingga menyebabkan hasil belajar siswa menjadi rendah.

Dikarenakan setiap siswa mempunyai hasil dan kebutuhan sendiri-sendiri, situasi dan kondisi dimana tempat anak tinggal akan ikut berpengaruh terhadap hasil belajarnya, misalnya kebutuhan anak yang tinggal di kota, di desa, di daerah pantai berbeda dengan yang tinggal dipegunungan, anak yang akan bersekolah di perguruan tinggi berbeda dengan anak yang akan bekerja setelah tamat SMA, bahkan bahan ajaran dan cara penyampaian sedapat mungkin disesuaikan dengan hasil dan kebutuhan tersebut maka pendidik mengupayakan dengan berbagai cara agar minat dan kebutuhan itu dapat terpenuhi. Setiap pengajaran sangat perlu memperhatikan hasil belajar dan kebutuhan, sebab keduanya akan menjadi penyebab tumbuhnya perhatian yang menarik hasil dan dibutuhkan oleh anak.

\section{Penggunaan Alat Peraga dalam} Meningkatkan Hasil Belajar pada Materi Geometri Ruang.

Alat peraga merupakan alat bantu yang termasuk dalam unsur dinamis dalam belajar. Kedudukannya juga penting karena dapat membantu siswa dalam belajar. Sebuah alat peraga dapat membantu dalam pembelajaran matematika yang bersifat abstrak yang kemudian dapat dikongkritkan. Sudjana dan Rivai (1990:3) menyatakan, taraf berpikir 
manusia mengikuti tahap perkembangan dimulai dari berpikir konkret menuju ke berpikir abstrak, dimulai dari berpikir sederhana menuju ke berpikir kompleks sehingga penggunaan media pengajaran dalam proses belajar mengajar erat kaitannya dengan tahapan berpikir tersebut sebab hal-hal yang abstrak dapat di konkretkan, dan hal-hal yang kompleks dapat disederhanakan

Selain itu juga alat peraga dapat menjadikan pembelajaran matematika geometri bangun ruang yang biasanya kurang menarik menjadi menarik. Khususnya penggunaan alat peraga rangka kubus dapat menumbuhkan minat siswa dalam mempelajari geometri ruang pada kubus. Hal ini dikarenakan siswa akan melihat, mendengar dan mengaplikasinnya secara mandiri dalam kehidupan sehari-hari. Hal ini dikarenakan kemampuan mengingat seseorang rata-rata jika hanya dengan mendengar $20 \%$, hanya dengan melihat $30 \%$, dengan melihat dan mendengar 50\%, dengan melihat, mendengar dan diskusi 70\%, dengan melihat, mendengar, diskusi dan menggunakan $90 \%$.

Tingkat kemampuan dalam memahami geometri bangun ruang berdasarkan pengalaman penulis, sebelum memulai pembelajaran, siswa dibawah bimbingan guru diminta membuat sendiri kerangka bangun ruang dengan memanfaatkan alam sekitar misalkan kayu atau bambu. Kegiatan ini dilakukan di luar jam pelajaran, setelah selesai kerangka tersebut di bawa pada saat pembelajaran pada pertemuan berikutnya. Pada awal pembelajaran setelah kegiatan apersepsi siswa mengamati dan membandingkan rangka kubus yang telah dibuat dengan teman lainnya. Kemudian guru memberikan lembar kerja siswa yang berisi masalah dan siswa diminta untuk menyelesaikan masalah tersebut. Guru hanya sebagai fasilitator atau sebagai pembimbing siswa untuk menyelesaikan permasalahan. Masing-masing siswa bekerja menggunakan alat peraga yang telah buat.

Siswa dengan menggunakan alat peraga masing-masing, mulai tampak aktif dalam menyelesaikan permasalahan yang diberikan. Salah satunya menentukan jarak antar titik, titik ke garis dan titik ke bidang, siswa menghubungkannya dengan menggunakan benang wol. Sehingga tampak jarak yang diperoleh adalah jarak terpendek yang membentuk garis tegak lurus yang selama ini siswa belum mampu mengabstraksikannya. Selain itu, keaktifan siswa dalam pembelajaran menggambarkan mulai tumbuhnya motivasi dalam diri siswa. Motivasi yang dimunculkan berasal dari luar dan akhirnya muncul dari dalam diri siswa itu sendiri. Hal ini nampak dari antusias siswa dalam menyelesaiakan permasalahan.

Penggunaan alat peraga rangka kubus pada materi geometri bangun ruang mampu menghasilkan generalisasi atau kesimpulan abstrak dari representasi konkret. Maksudnya, dengan bantuan alat peraga yang sifatnya konkret, siswa diharapkan dapat menarik kesimpulan. Menurut penulis, alat peraga harus dibuat sebaik mungkin, menarik untuk diamati, dan mendorong siswa untuk bersifat penasaran (curious), sehingga diharapkan motivasi belajarnya semakin meningkat yang 
berdampak pada meningkatnya hasil belajar siswa. Alat peraga yang digunakan penulis juga diharapkan menumbuhkan daya imajinsi dalam diri siswa. Misalnya alat peraga bendabenda ruang dapat mendorong siswa dalam meningkatkan daya titik ruangnya, mampu membandingkannya dengan benda-benda sekitar dalam lingkungannya sehari-hari, dan mampu menganalisis sifat-sifat benda yang dihadapinya itu. Misalnya, jika siswa telah menggunakan alat peraga kubus, untuk mempelajari sifat-sifat yang dimiliki kubus, siswa terdorong untuk meneliti sifat-sifat benda nyata di alam sekitar yang memiliki bentuk serupa dengan kubus.

\section{Hasil Penyajian Data Nilai Formatif Siswa}

Adapun perlakuan yang diberikan pada pertemuan pertama guru mengajarkan mengenai geometri ruang (menentukan jarak antar titik, titik ke garis dan titik ke bidang) dengan menggunakan metode ekspositori. Guru menjelaskan materi yang dipelajari dan kemudian dilanjutkan dengan tanya jawab antara siswa-siswa, siswa guru, dan gurusiswa. Namun hal ini kurang menarik perhatian atau minat siswa untuk mempelajari geometri ruang dengan sungguh-sungguh. Hal ini dapat dilihat dari rata-rata hasil belajar post-test siswa yang masih rendah.

Karena penulis tidak puas dengan hasil belajar yang rendah maka penulis mengadakan pembelajaran kembali dengan menggunakan alat peraga rangka kubus pada materi geometri ruang (menentukan jarak antar titik, titik ke garis, dan titik ke bidang) dengan membentuk siswa menjadi berkelompok. Sehingga setelah perlakukan tersebut diberikan postes dan diperoleh hasil belajar siswa berupa skor.

Hasil belajar siswa berupa skor postest yang diperoleh penulis setelah selesai mengajar materi geometri ruang (menentukan jarak antar titik, titik ke garis dan titik ke bidang). Perbandingan rata-rata hasil belajar siswa yang sebelum dan sesudah menggunakan alat peraga rangka kubus dapat dilihat secara ringkas pada tabel 3.1 berikut:

Tabel 3.1 Hasil Belajar Siswa

\begin{tabular}{lcc}
\hline Keterangan & $\begin{array}{l}\text { Sebelum } \\
\text { menggunakan } \\
\text { alat peraga }\end{array}$ & $\begin{array}{l}\text { Setelah } \\
\text { menggunakan } \\
\text { alat peraga }\end{array}$ \\
\hline $\begin{array}{l}\text { Rata-rata hasil } \\
\text { belajar }\end{array}$ & 59,2 & 88,4 \\
\hline $\begin{array}{l}\text { Banyak siswa } \\
\text { yang tuntas }\end{array}$ & 10 & 23 \\
\hline $\begin{array}{l}\text { Persentase } \\
\text { banyaknya siswa } \\
\text { yang tuntas (\%) }\end{array}$ & 15 & 2 \\
\hline $\begin{array}{l}\text { Ketuntasan } \\
\text { secara klasikal }\end{array}$ & $40 \%$ & $92 \%$ \\
\hline
\end{tabular}

Berdasarkan perhitungan secara keseluruhan siswa kelas X SMAN 2 Sekadau yang mencapai ketuntasan belajar yaitu $40 \%$ sebelum mengunakan alat peraga dan $88,4 \%$ setelah menggunakan alat peraga. Sehingga dapat dikatakan terjadi peningkatan yang signifikan saat penggunan alat peraga rangka kubus pada materi geometri bangun ruang (menentukan jarak pada bangun ruang). Sehingga untuk meningkatkan hasil belajar siswa yang mengalami kesulitan dalam mengkonkretkan konsep abstrak pada geometri ruang dapat menggunakan alat peraga berupa rangka kubus atau rangka bangun ruang lainnya seperti balok, tabung, kerucut, limas, prisma dan bola. 
Hal ini sanggat membantu proses pembelajaran, siswa menjadi lebih aktif dalam menyelesaikan masalah yang diberikan menggunakan alat peraga yang telah ditentukan. Konsep yang awalnya abstrak menjadi sangat konkret bagi siswa di kelas $\mathrm{X}$ SMAN 2 Sekadau. Hal ini juga bisa dilihat dari rata-rata hasil belajar post-test setelah menggunakan alat peraga meningkat sebesar $29,2 \%$ dari $59.2 \%$ menjadi $88,4 \%$.

\section{KESIMPULAN}

Berdasarkan pembahasan pada Bab III maka dapat disimpulkan Faktor-faktor penyebab rendahnya hasil belajar, diantarnya: (1) faktor internal meliputi fisiologis dan psikologis, (2) faktor eksternal meliputi keluarga, sekolah, dan masyarakat. Penggunaan alat peraga rangka kubus dapat meningkatkan hasil belajar siswa kelas $\mathrm{X}$ SMAN 2 Sekadau pada materi geometri ruang (menentukan jarak antar titik, titik ke garis, dan titik ke bidng) sebesar 29,2\%. Pembelajaran menggunakan alat peraga rangka kubus mencapai ketuntasan secara klasikal sebesar $88,4 \%$.

Saran yang dapat disampaikan penulis kepada para pembaca adalah dalam meningkatkan hasil belajar siswa, guru dapat menggunakan alat peraga yang disesuaikan dengan materi yang akan disampaikan.

\section{DAFTAR PUSTAKA}

Depdiknas. 2007. Kurikulum Tingkat Satuan Pendidikan. Jakarta: Depdiknas.

Dimyati dan Mudjiono. 2006. Belajar dan Pembelajaran. Jakarta: PT Rineke Cipta.

Nawawi, H. 2004. Metode Penelitian Bidang Sosial cetakan ke-5. Jakarta: Gajah Mada University Press.

Priyono. 2016. Metode Penelitian Kuantitatif. Surabaya: Zifatama

Sudjana, N. 1998. Dasar-dasar Proses Belajar Mengajar cetakan ke-empat. Bandung: Sinar Baru Algesindo.

Sudjana dan Rivai. 1990. Media Pengajaran cetakkan ke-empat. Bandung: Sinar Baru.

Sugiyono. 2017. Metode Penelitian Kuntitatif kualitatif dan R\&d. Bandung: Alfabeta.

Suyitno. 2003. Konsep Pembelajaran Matematika Dasar. Jakarta: Pustaka Baru. 